\title{
ASSESSMENT OF HUMAN DENTAL PULP STEM CELLS WITH CHITOSAN SCAFFOLD VERSUS XENOGRAFTS IN IMPLANT OSSEOINTEGRATION. AN EXPERIMENTAL STUDY IN A RABBIT MODEL
}

\author{
Abeer Kamal * and Eman Khalil **
}

\begin{abstract}
Background: Human dental pulp stem cells (hDPSCs) considered as a promising source of mesenchymal stem cells for bone regeneration. It can be used to improve osseointegration of dental implant and improve its stability.
\end{abstract}

Objectives: Assessment of bone healing and implant osseointegration by the use of human dental pulp stem cells with chitosan scaffold and compared the result with xenografts in a rabbit model.

Materials \&Methods: Eighteen adult white rabbits were used in this study. They were distributed equally into three groups, group I, human dental pulp stem cells and chitosan was used before implant insertion in the tibia. Group II, xenografts were used and group III was the control group. After 12 weeks the animals were sacrificed and assessment of bone formation was accomplished by the used of the histological section using H\&E, Masson stain as well as scanning electron microscope (SEM).

Results: The highest mean area percent was detected in the stem cell group, followed by the xenograft group, while the control group revealed the lowest mean area percent value. Analysis of variance test revealed a highly significant difference between the studied groups $(\mathrm{P}=0.00)$. Comparison between the gap distances $(\mu \mathrm{m})$ in the three groups measured by electron microscope indicated that the lowest mean gap distance was presented in the stem cells group.

Conclusion: human dental pulp stem cells coupled with chitosan is a promising method for bone formation and maturation around dental implant and help in osseointegration.

KEY WORDS: Human Dental Pulp Stem Cells, Chitosan, Xenografts, bone healing, osseointegration.

* Oral Surgery and Maxillofacial Department

** Oral Medicine and Periodontology Department 


\section{INTRODUCTION}

Mesenchymal stem cells (MSCs) are being investigated as an appropriate type of stem cells to be used in bone tissue engineering due to their ability to differentiate into osteoblasts and endothelial cells. ${ }^{(1)}$ Human dental pulp stem cells hDPSCs represents a promising source of mesenchymal stem cells for bone regeneration. The advantages of MSCs isolated from human dental pulp tissue are its easy accessibility, great proliferative and multilineage differentiation potential. They are tremendously proliferative and able of bony, dentin, adipose tissue, cartilage, and neurogenic differentiation. ${ }^{(2-5)}$

The process of bone regeneration by the stem cells was completed by adding specific biomaterials that act as a scaffold. This carrier allows the cells to proliferate migrate, and transform into bone cells. It is also necessary for local angiogenesis to provide the necessary nutrients for the precise development of the bone tissue. (2) The scaffold must also be biodegradable gradually in harmony with bone regeneration to provide spaces for natural bone growth. Materials used to fabricate bone scaffolds includes natural and artificial bioceramics, natural and synthetic polymers and mixtures of polymers with bioceramics. The most widely used natural polymers in bone tissue engineering include collagen, alginate, and chitosan. ${ }^{(6)}$

Chitosan scaffold (poly-N-acetyl glucosaminoglycan), a carbohydrate biopolymer is a natural copolymer derived from the alkaline deacetylation of chitin. It has been suggested as a scaffold for tissue regeneration. It was detected that in cell culture media treated with chitosan monomer (D-glucosamine hydrochloride) a significant increase of alkaline phosphatase activity and BMP-2 gene expression of the developed osteoblasts. ${ }^{(7,8,9)}$ Chitosan has many valuable properties including biocompatibility, biodegradability, nonimmunogenic, with no inflammatory or allergic reactions. It has an antimicrobial and antifungal effect and non-toxic reactions after implantation, injection, or topical application. ${ }^{(10-14)}$ it is fabricated in different forms including powders, granules, filament, sponge, or as a composite with cotton or polyester. The degradation rate can be controlled by cross-linking. The progress of a chitosan that can support osteogenesis may be significant not only in the quality of newly formed bone matrix, but also in the ability of this tissue to incorporate with the host ground. ${ }^{(15,16)}$

Xenografts are the use of living cells, tissues or organs after treatment from an animal, nonhuman source such as bovine, equine, or coral that are transplanted and placed into a human. In the last few decades, the bovine bone has become a common source for the preparation of bone substitutes. It has a good osteoconductive capacity with low immunologic reactions after protein elimination. The xenograft provides long-term volume stability. The decreased risk of infectivity to the tissue is set to a minimum after treatment with a strong alkaline solution. ${ }^{(17-19)}$ The efficacy of xenografts is due to a combination of factors osteoconductivity and slow resorbability without interference with osseointegration by the residual graft material. ${ }^{(20)}$ Xenografts could be used in the different field as maxillary sinus augmentation, (21) around the dental implant in the deficient ridge, (22) intrabony and furcation defects in periodontal regeneration, ${ }^{(23)}$ filling of bony defects after cystic lesions enucleation of the jaws and for correction of skeletal deformities with facial asymmetry. ${ }^{(24)}$

The aim of the current research was to assess bone healing and implant osseointegration by the use of human dental pulp stem cells coupled with chitosan scaffold and compared the result with xenografts. An experimental model has been used. The following calipers were utilized for assessment, histological examination using H\&E stain, Masson stain for assessment of the percentage of newly formed bone. Scanning electron microscope SEM was employed for gap measurements in $(\mu \mathrm{m})$ between the bone and the placed dental implant. 


\section{MATERIAL AND METHODS}

This study was accomplished according to the experimental research ethics committee of the animal house, Faculty of Medicine, Cairo University. It was conducted on eighteen pathogenfree adult white rabbits (2500-3500 gm.). The animals were checked by the veterinarian staff just on arrival and quarantined for 1 week. Isolation and culture of mesenchymal cells from human dental pulp tissues was obtained from impacted teeth extracted two weeks before surgical procedures in the rabbits. The process of attaining stem cells was performed at stem cell Laboratory, Faculty of Medicine, Cairo University, Egypt, according to the technique described by Di Benedetto et al ${ }^{(25)}$ Figure (1). Chitosan gel was synthesis according to the technique reported by Senel et al (26).

\section{Isolation and culture of mesenchymal cells from human dental pulp tissues ${ }^{(25)}$ :}

Human dental stem cells were harvested from the attached dental pulps separated from impacted tooth. The dental tissues were processed in a solution of $0.1 \mathrm{U} / \mathrm{ml}$ collagenase type II (Sigma) for $60 \mathrm{~min}$. at $37^{\circ} \mathrm{C}$ then centrifugation at $500 \mathrm{xg}$ for 5 minutes in phosphate buffer saline. The cells debris was detached by passing mix through a $40 \mathrm{~mm}$ nylon cell strainer (BD FalconTM, BD Biosciences, Franklin Lakes, NJ, and USA) and, the dental pulp stem cells were expanded in vitro. hDSCs were dissociated on confluence using a $0.25 \%(\mathrm{w} / \mathrm{v})$ trypsin-EDTA (Gibco). Cell pellets was obtained by centrifugation at $500 \mathrm{xg}$ for 5 minutes. Cells were then re-cultured in Dulbecco's modified eagle's medium (ADMEM) supplemented with $10 \% \mathrm{PBS}, 100 \mathrm{U} / \mathrm{ml}$ penicillin and $100 \mathrm{mg} / \mathrm{ml}$ streptomycin at $37^{\circ} \mathrm{C}$ in a humidified atmosphere of $5 \% \mathrm{CO}_{2}$. The culture medium was changed twice a week and passages were expanded three times for further analysis and characterization. Figure 1.

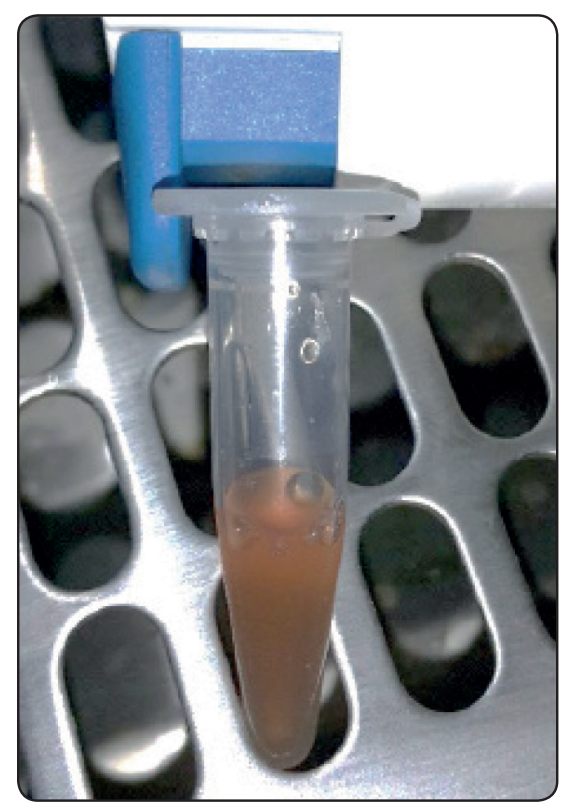

Fig. (1) Prepared (hDMSCs)

\section{Surgical procedure:}

Two weeks after preparation of human mesenchymal dental pulp stem cells, surgery was performed in the three groups of animals. The animals were anesthetized under general anesthesia using the intramuscular injection of Ketamine 20-50 mg/ kg IM (Ketamine HCL injection USP, Rotexmedica, Germany) and Xylazine 2\%, 10 mg/kg IM, (Rompun. Bayer AG, Leverkusen. Germany). (27) Scrubbing of tibia and knee joint was performed in a routine way. Skin incision was carried-out at the medial side of the knee joint under the routine aseptic technique. Dissection was performed to expose the tibia platform, from the center of the tibia a round surgical bur was used to mark the implant site followed by gradual drilling accompanied by copious irrigation with saline. Each animal received two titanium implant in the tibia $(3.4 \mathrm{~mm}$ in diameter and $8 \mathrm{~mm}$ in length) (Super Line Dentium Implant System. Dentium Co., Ltd. Seoul, Korea). The sample (18 rabbits) was distributed equally into three groups, group I, the implant bed was filled by a mixture of human dental pulp stem cells and chitosan, then the implant was inserted and the covered screw was 
placed. (Figure 2 and 3). Group II, the implant bed was filled by xenografts (Bio-Oss ${ }^{\circledR}$ small granules. Geistlich Pharma North America Inc.), then the implant was inserted, and group III, the implant inserted without adding of any material and it was considered as control group. The wound was closed and sutured with 3-0 Vicryl sutures material (polyglactin 910 Ethicon). The animals received the following drugs postoperatively: Crystalline penicillin (Misr Co. for pharm. Ind. Cairo. Egypt) dosage: $10 \mathrm{mg} / \mathrm{kg}$. I.M injection every 12 hour for 5 days and Cataflam (diclofenac potassium $75 \mathrm{mg}$, Novartis Pharma) ampoule I.M injection, dosage: $5 \mathrm{mg} / \mathrm{kg}$, per day for 3 days.

At 12 weeks after implant insertion, the animals were sacrificed for sample preparation. A portion of

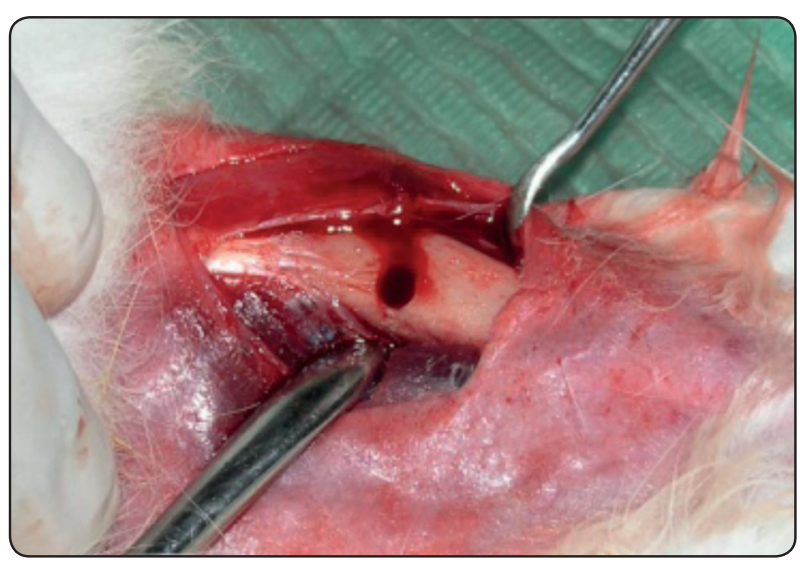

Fig. (2) the first implant bed and

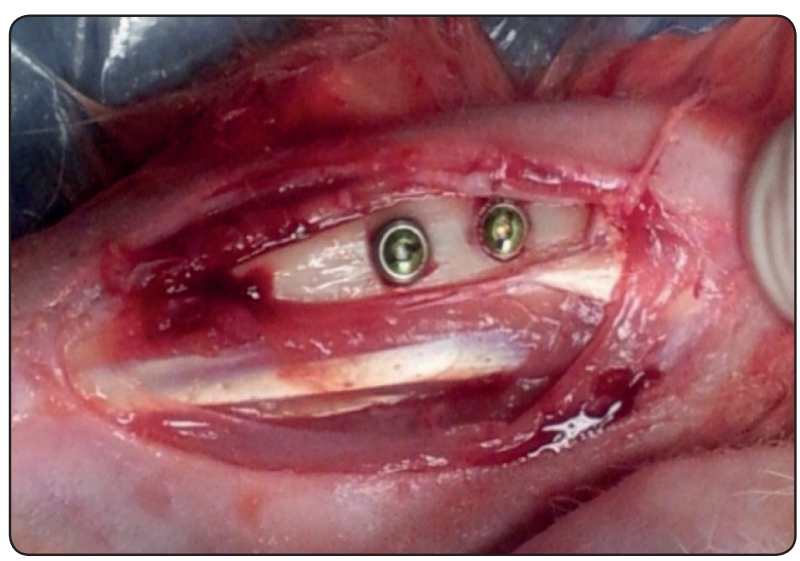

Fig. (3) insertion of two implants in tibia the tibia that included the implants was sectioned using a diamond burr. All samples were immersed immediately in a $10 \%$ formaldehyde-buffered fixative solution (Sigma-Aldrich). Assessments of the results of bone formation were performed through histologic section using $\mathrm{H} \& \mathrm{E}$ and Masson stain for assessment of the percentage of newly formed bone. The area percent of newly formed bone was estimated using Leica Quin 500 analyzer computer system, (Leica Microsystems, Switzerland). Department of Oral and Maxillofacial Pathology. Faculty of Dentistry. Cairo University. The area percent of newlyformed bone was estimated in 8 different fields in each group with magnification (X100). The scanning electron microscope (a JEOL 6300F - Eching, Germany) was used to assess the size of the gap between implant threads and bone for osseointegration in National Research Center, Giza. It was measured by $\mu \mathrm{m}$ using 4000-6000X. The specimen containing implant was prepared for electron microscope study according to the Hipp et al ${ }^{(28)}$ technique.

\section{Statistical analysis}

Mean and standard deviation was presented for each group. Analysis of variance (ANOVA) test was used for comparison of the difference between the three groups. Tukey's post hoc test as well as ANOVA, test was performed to reveal any significant difference. The unpaired $\mathrm{T}$ test was used for pairwise comparisons. $\mathrm{P}$ value $\leq 0.05$ was considered statistically significant. Statistical analysis was done using SPSS test. Version 20 for Windows 2016.

\section{RESULTS}

All 18 animals tolerated the general anesthesia without any complications. One experimental animal developed an extensive inflammatory reaction postoperatively and it was excluded and replaced by another one. 


\section{Histological findings H\&E, Masson stain}

Group, I (stem cells and chitosan) showed large masses of newly formed calcified tissue with regularly arranged marrow spaces. The detected newly formed bone was dense and more mature than that of group II and III with no marked inflammatory reaction or fibrosis (Figure 4a). The mean area percent of bone was detected by Masson stain in group I was (32.1 \pm 1.45$)$ and this was highly significant when compared with the other two groups with $\mathrm{P}$ - value $\mathrm{P}=0.00$. (Figure $4 \mathrm{~b}$ ) (Table 1)

Group, II (xenografts) revealed some areas composed of newly formed calcified tissue with a residual layer of granulation tissue with a mild inflammatory response. The newly formed woven bone was thinner, less dense and less mature than in group I. The number of bone forming cells entrapped in bone trabeculae was little (Figure 5a) when compared with group I but higher than group III (control). The mean area percent of bone was detected by Masson stain in group II was (24.6 \pm 1.63$)$ (Figure 5b) (Table 1).

Group, III (control group) displayed connective tissue composed of collagen fiber bundles with little fibroblast and inflammatory cells suggesting granulation tissue. Mild bone formation could be detected in the form of multiple small ectopic foci of osteoid bone (Figure 6a). The mean area percent of bone was detected by Masson stain in group III was (12.4 \pm 1.37$)$ (Figure 6b) (Table 1).

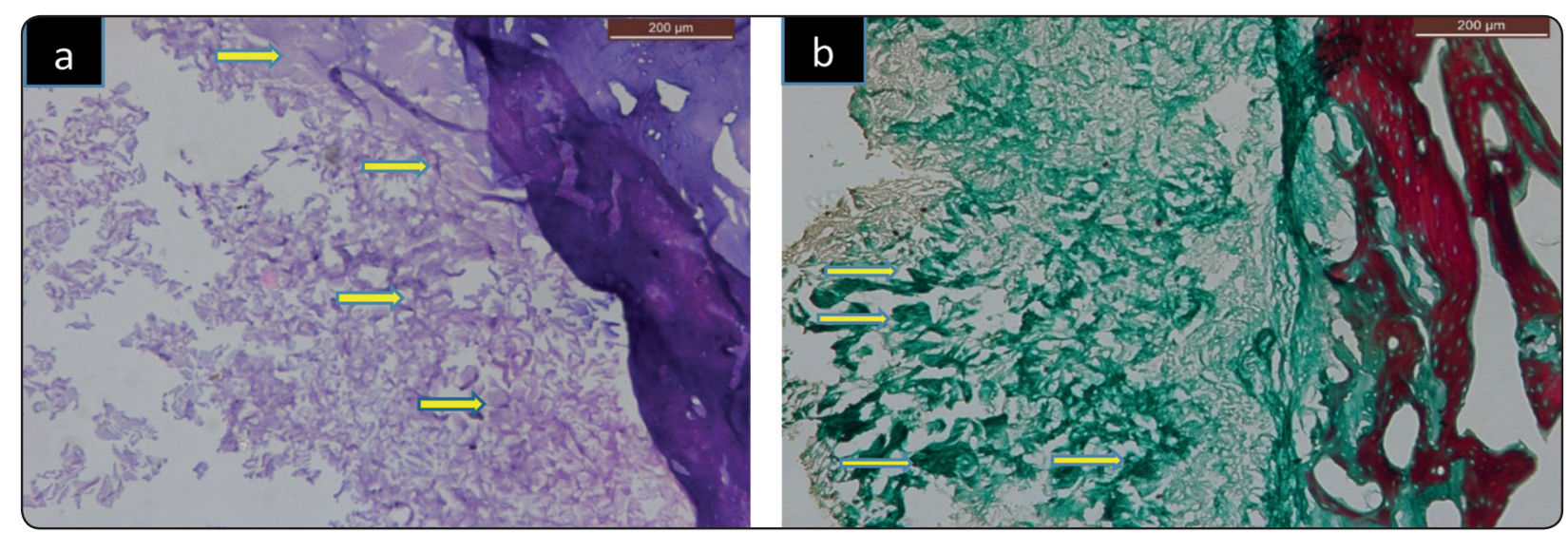

Fig. (4): Photomicrograph in the (group I) stem cells showing (a) large masses of newly formed calcified tissue (yellow arrows) (H\&E x 100). (b) Many areas of newly formed calcified tissue (yellow arrow) (Masson x100).

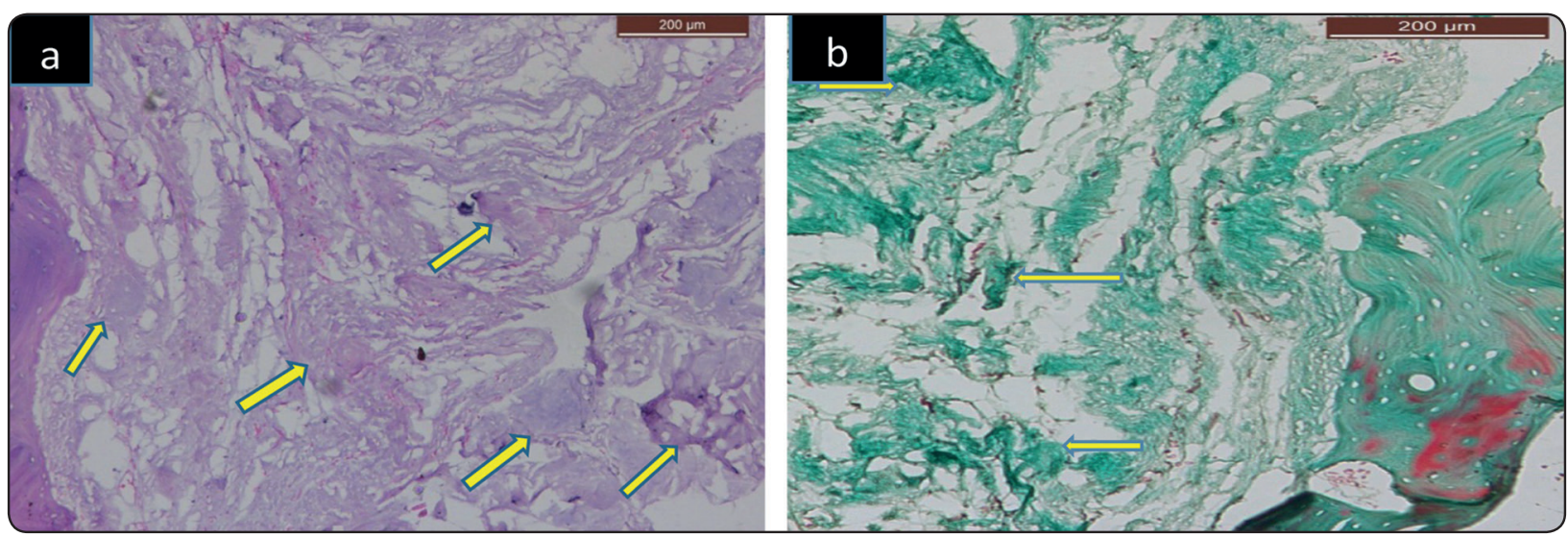

Fig. (5): Photomicrograph in the (group II) xenografts showing (a) some areas composed of newly formed calcified tissue (yellow arrows) (H\&E x 100). (b) Some areas of newly formed calcified tissue (yellow arrows)(Masson x 100). 


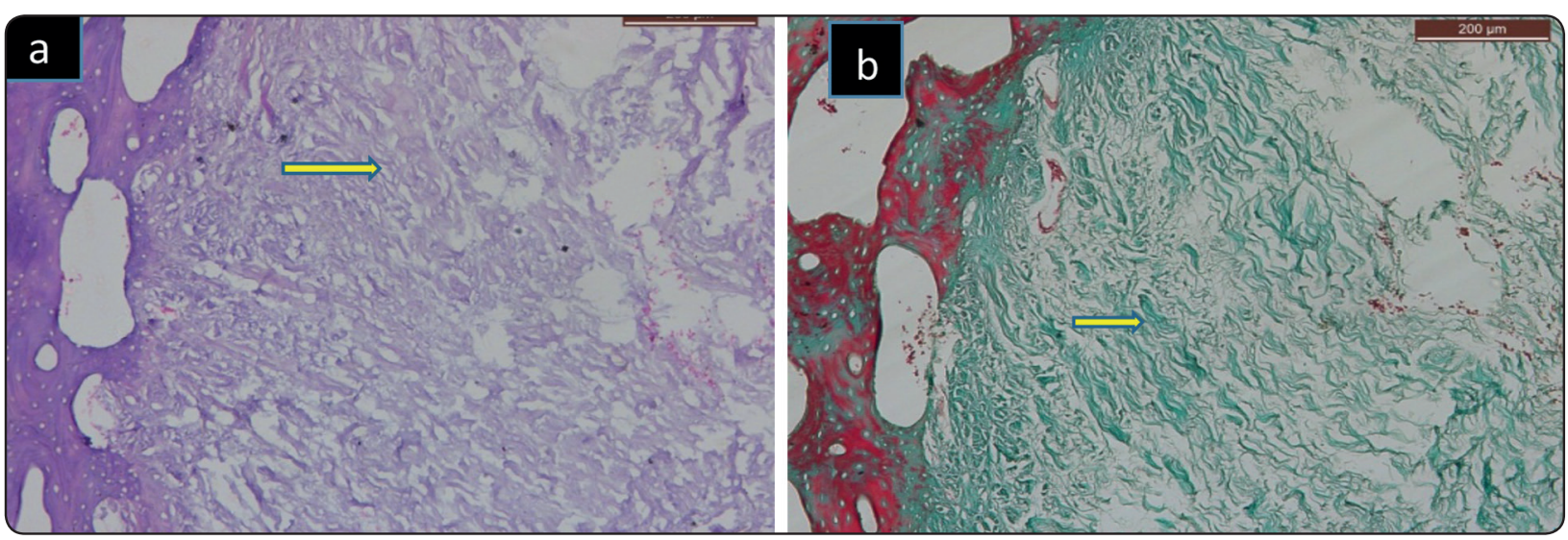

Fig. (6): Photomicrograph in the (group III) control group showing (a) connective tissue composed of collagen fiber bundles (yellow arrow) (H\&E x 100). (b) Connective tissue (yellow arrow). (Masson x100)

The highest mean area percent was detected in the stem cell group $(32.1 \pm 1.45)$, followed by the xenografts group $(24.6 \pm 1.63)$ while the control group revealed the lowest mean area percent value (12.4 \pm 1.37$)$. ANOVA test revealed a highly significant difference between the studied groups $(\mathrm{P}=0.00)$ (Table 1), (Figure 7).

Comparing each two groups together using Post Hoc Tukey test revealed a significant difference between the control group III and the xenografts group II ( $\mathrm{p}=0.00)$, control group (III) and the stem cell with chitosan group (I) $(\mathrm{p}<0.05)$ as well as between the xenografts group (II) and the stem cell

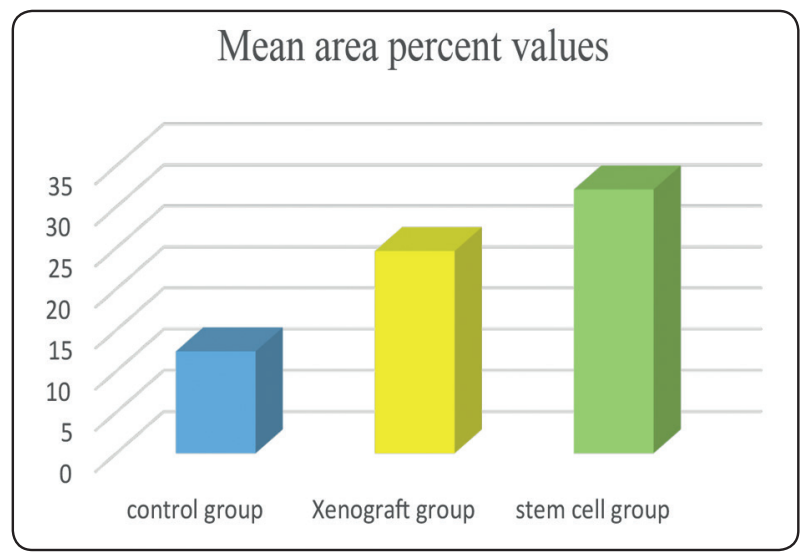

Fig. (7): Bar chart showing the mean area percent values for the studied groups. group (I) ( $\mathrm{p}=0.00)$. Table (2), Figure. (7)

TABLE (1): Comparison of mean area percent values between the studied groups (ANOVA test)

\begin{tabular}{|c|c|c|c|c|}
\hline $\begin{array}{ll}\text { Mean area } \% & \text { Group }\end{array}$ & Stem cell group & Xenografts group & Control group & P value \\
\hline Mean \pm SD & $32.1 \pm 1.45$ & $24.6 \pm 1.63$ & $12.4 \pm 1.37$ & 0.00 \\
\hline
\end{tabular}

Significant at $P \leq 0.05$

TABLE (2): Comparing each two groups together (Post hoc Tukey's test)

\begin{tabular}{|c|c|c|c|}
\hline Groups & Stem cell group & Xenografts group & Control group \\
\hline Control group & $\mathrm{P}=0.04$ & $\mathrm{P}=0.00$ & - \\
\hline Xenograft group & $\mathrm{P}=0.00$ & - & $\mathrm{P}=0.00$ \\
\hline Stem cell group & - & $\mathrm{P}=0.00$ & $\mathrm{P}=0.04$ \\
\hline
\end{tabular}

Significant at $P \leq 0.05$ 


\section{Electron Microscope scanning results:}

Comparison between the gap distances $(\mu \mathrm{m})$ in the three groups measured by electron microscope indicated that the lowest mean gap distance was presented in the group I (stem cells with chitosan) with the mean $6.4(\mu \mathrm{m})$ and this was statistically significant with p- value 0.041. Figure (8). Table (3).
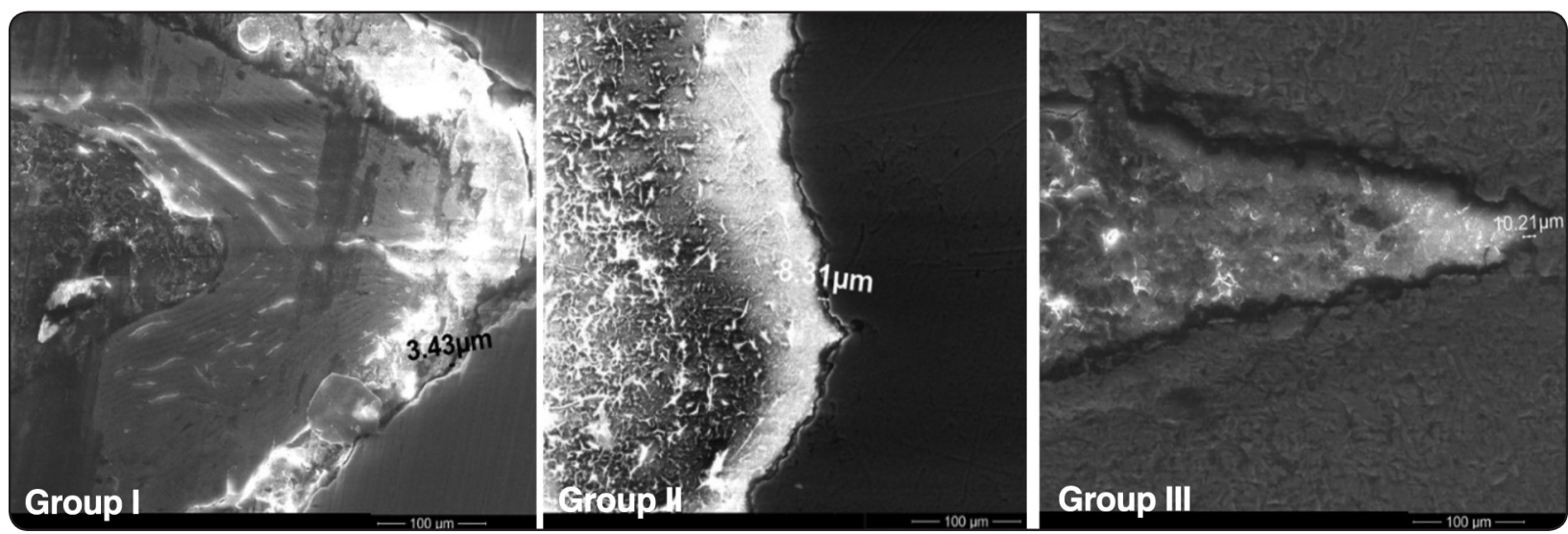

Fig. (8) Scanning Electron microscope of the three group showing gap distance $(\mu \mathrm{m})$ indicate the lowest mean gap distance $(\mu \mathrm{m})$ in group I stem cell with chitosan group.

Table (3): Comparison between gap distances $(\mu \mathrm{m})$ in the three groups. Mean, standard deviation (SD) values and results of one-way ANOVA and Tukey's tests for

\begin{tabular}{c|cccc}
\hline Gap distance & Stem cell group & Xenografts group & Control group & P value \\
\hline Mean $\pm \mathrm{SD}$ & $6.4 \pm 1.8$ & $8.8 \pm 1.5$ & $9.3 \pm 1.6$ & 0.041 \\
\hline
\end{tabular}

Significant at $P \leq 0.05$

\section{DISCUSSIONS}

Osseointegration of dental implant in cases of bony defect or poor bone quality represents a surgical dilemma in the maxillofacial field. Many efforts have been reported to accelerate and augment bone formation and regeneration. Stem cells represent the new era in the bone healing and regeneration in the oral and maxillofacial field. It has promising and appropriate resources to overcome the problems of autologous bone graft, allografts, xenografts, or artificial bone substitutes. Several studies have been proved the ability of stem cells to induce bone regeneration for skeletal bone defects, maxillary sinus lifting procedure as well as healing of bone around the dental implants ${ }^{(29-33)}$. The present study was intended to use human dental pulp stem cells with chitosan scaffold versus Xenograft bone substitute for improvement of bone regeneration around dental implant in an experimental rabbit model. It was hoped to develop potent therapeutic methods to rapidly promote bone healing around dental implant with the result of increase osseointegration and dental implant stability.

Using a suitable scaffold with an appropriate architectural design is a prerequisite when using stem cells approach for bone regeneration. In the present study, chitosan scaffold has been used to deliver stem cells being non-toxic, biodegradable 
material, highly versatile promising material with many potential biomedical applications and free from any side effect. This opinion is concordance with many authors. ${ }^{(34-41)}$ Chitosan scaffold is essential carrier for the stem cells, it prevents rapid diffusion of cells away from the defect site as well as their susceptibility to uptake, catabolism or proteolysis resulting in an insufficient local concentration of the number of cells.

Rabbit was selected as an experimental model in the current study. The white rabbits have been shown to be more effective for evaluating the potential for bone formation and convenient for examining bone regeneration because of its effective accessibility. Rabbits show substantial intracortical remodeling, and have a more rapid bone turnover than rodents and even primates, the tibia is easily accessible due to minimal associated soft tissue, the mature rabbit can support 2- to 3-implants. The selection of the experimental model used in this study was in agreement with Baofeng et al ${ }^{(42)}$ Wancket ${ }^{(43)}$ Himanshu et al ${ }^{(44)}$ and Bressan et al. ${ }^{(45)}$

In the current research, the mean area percent of bone formation was significantly higher in stem cells group followed by xenograft group with lesser mean area percent of bone in control group. Owing to the fact that stem cells encourage early periimplant trabecular bone formation to ensures tissue anchorage that corresponds to biological fixation of the implant, ingrowth of more mature bone observed in group I (stem cells), with thick bony trabeculae and increasing osteocytes in their lacunae, support the higher positive effect of stem cells with chitosan scaffold on osseointegration compared with group II and control group. Once chitosan scaffold enriched with human dental pulp stem cells (hDSCs) were inserted around dental implant, several new blood vessels and new bone cells were detected with no inflammatory cells, thus higher bone regeneration process was mediated by the transplanted hDSCs that may act by starting to recruit endogenous stem cell by means of growth factor secretion without triggering any inflammatory response. These results are in agreement with the finding of Bressan et al. $(45,46)$

Scanning electron microscope analysis showed significant decreased in gap distance between implant threads and bone in group I as a result of the addition of stem cells with chitosan scaffold more than the other two groups. This finding suggests that dental pulp stem cells capable to induce greater bone formation as compared with Xenograft. This action might be related to the seeded stem cells in the porous chitosan scaffold with its lower level of resorption and this property may favor bone formation and stay in direct contact with implant surface as supported by the finding of Suh et al (47). Chitosan scaffolds with stem cells mixture allow effective cell seeding, nutrient, and waste transport to support cell metabolism. This could help cell attachment, proliferation, and aggregation. The newly formed bone trabeculae are clearly evident, more condensed, more mature and become connected with the original old bone with the result of the decreased gap measurement represented in the scanning electron microscope.

This observation detected in the current study allowed to conclude that the chitosan scaffolds used were able to preserve stem cells in direct contact with bone and implant threads for a longer time with the result greater bone percentage as well as lowest gap distance observed in the stem cells group. The differentiated hDSCs increase bone regeneration as detected and that the chitosan scaffold used can be a suitable carrier to entrap and maintain the cells. This finding is in concordant with the results presented by Kim et al ${ }^{(48)}$ and Michele et al. ${ }^{(49)}$

Conclusion: the results of the present study deduced that human dental pulp stem cells with chitosan scaffold is an effective and promising method that has significantly enhanced new bone formation around dental implant suggesting its potency in inducing bone regeneration in the defective area around the dental implant. 


\section{ACKNOWLEDGMENTS}

Dr. Dina Sabry: Professor of Medical Biochemistry and Molecular Biology, Faculty of Medicine, Cairo University, Cairo. For her help in the production of stem cells in this study. Also for Dr. Nermin Raoof: Associate Prof. of Oral and Maxillofacial Pathology. Faculty of Dentistry. Cairo University, Cairo, Egypt. For her help in performing pathological part of this research.

\section{REFERENCES:}

1. Shi S, Bartold PM, Miura M, Seo BM, Robey PG, Gronthos S: The efficacy of mesenchymal stem cells to regenerate and repair dental structures. Orthod Craniofac Res. 2005; 8: 191-199.

2. Gronthos S, Brahim J, Li W, Fisher LW, Cherman N, Boyde A, DenBesten P, Robey PG, Shi S: Stem cell properties of human dental pulp stem cells. J Dent Res. 2002; 81: 531-535.

3. Graziano A, d'Aquino R, Laino G, Papaccio G: Dental pulp stem cells: a promising tool for bone regeneration. Stem Cell Rev. 2008; 4: 21-26.

4. Casagrande L, Cordeiro MM, Nör SA: Dental pulp stem cells in regenerative dentistry. Odontology 2011; 99: 1-7.

5. Gronthos S, Mankani M, Brahim J: Postnatal human dental pulp stem cells (DPSCs) in vitro and in vivo. Proc Natl Acad Sci. 2000; 97: 13625-13630.

6. Saaid Ayesh Alshehadat, Htun Aung Thu, Suzina Sheikh Abdul Hamid , Asma Abdullah Nurul , Samsudin Abdul Rani , Azlina Ahmad: Scaffolds for dental pulp tissue regeneration: A review. International Dental \& Medical Journal of Advanced Research. 2016, 2, 1-12

7. Matsunaga T, Yanagiguchi K, Yamada S, Ohara N, Ikeda T, Hayashi Y: Chitosan monomer promotes tissue regeneration on dental pulp wounds. J Biomed Mater Res. 2006; 76:711-20.

8. Park SJ, Li Z, Hwang IN, Huh KM, Min KS: Glycol chitin based thermoresponsive hydrogel scaffold supplemented with enamel matrix derivative promotes odontogenic differentiation of human dental pulp cells. J Endod. 2013; 39:1001-7.

9. Rodríguez-Vázquez M, Vega-Ruiz B, Ramos-Zúñiga R, Saldaña-Koppel DA, Quiñones-Olvera LF: Chitosan and Its Potential Use as a Scaffold for Tissue Engineering in Regenerative Medicine. Biomed Res Int. 2015; 2015:821279.

10. Chatelet C, Damour O, Domard A.: Influence of the degree of acetylation on some biological properties of chitosan films. Biomaterials. 2001; 22: 261-268.

11. Muzzarelli RA.: Human enzymatic activities related to the therapeutic administration of chitin derivatives. Cell Mol Life Sci. 1997; 53:131-40.

12. J. Jagur-Grodzinski: Biomedical application of functional polymers. Reactive and Functional Polymers. 1999; 39: 99- 138.

13. Peh K, Khan T, Ch'ng H.: Mechanical, bioadhesive strength and biological evaluations of chitosan films for wound dressing. J Pharm Pharm Sci. 2000; 3:303-11.

14. Amaral IF, Granja PL, Barbosa MA.: Chemical modification of chitosan by phosphorylation: an XPS, FTIR and SEM study. J Biomater Sci Polym Ed. 2005; 16:1575-93.

15. Varshosaz J.: The promise of chitosan microspheres in drug delivery systems. Expert Opin Drug Deliv. 2007; 4:263-73.

16. Lee YM, Park YJ, Lee SJ, Ku Y, Han SB, Choi SM, Klokkevold PR, Chung CP.: Tissue Engineered bone formation using Chitosan/Tricalcium phosphate sponges periodontal. J Periodontol. 2000; 71:410-7

17. Wenz B, Oesch B, Horst M.: Analysis of the risk of transmitting bovine spongiform encephalopathy through bone grafts derived from bovine bone. Biomaterials. 2001; 22:1599-606.

18. Calasans-Maia M, Resende R, Fernandes G, Calasans-Maia J, Alves AT, Granjeiro JM.: A randomized controlled clinical trial to evaluate a new xenograft for alveolar socket preservation. Clin Oral Implants Res. 2014; 25:1125-30

19. Milani S, Dal Pozzo L, Rasperini G, Sforza C, Dellavia C.: Deproteinized bovine bone remodeling pattern in alveolar socket: a clinical immunohistological evaluation. Clin Oral Implants Res. 2016; 27:295-302.

20. Del Fabbro M, Testori T, Francetti L, Weinstein R.: Systematic review of survival rates for implants placed in the grafted maxillary sinus. Int J Periodontics Restorative Dent. 2004; 24:565-77.

21. Barone A, Crespi R, Aldini NN, Fini M, Giardino R, Covani U.: Maxillary sinus augmentation: Histologic and histomorphometric analysis. Int J Oral Maxillofac Implants. 2005; 20:519-25. 
22. Wallace SS, Froum SJ.: Effect of maxillary sinus augmentation on the survival of endosseous dental implants. A systematic review. Ann Periodontol. 2003; 8:328-43

23. Robert E. Cohen, Asim Alsuwaiyan, Bing-Yan Wang: Xenografts and Periodontal Regeneration. Journal of Orthodontics \& Endodontics 1: 1-6: 2015

24. Chowdhury SR, Sapru BL, Awasthi PN.: Clinicoradiographic evaluation of xenografts in maxillofacial surgery. Med J Armed Forces India. 2001; 57:281-4.

25. Di Benedetto A, Carbone C, and Mori G: Dental pulp stem cells isolation and osteogenic differentiation: a good promise for tissue engineering. Methods Mol Biol. 2014; 1210:117-30

26. Senel S, McClure SJ.: Potential applications of chitosan in veterinary medicine. Adv Drug Deliv Rev. 2004; 56: 1467-80.

27. Carpenter J, Marion CJ.: Exotic Animal Formulary, 4th edition eds. Elsevier Saunders. St. Louis, Missouri, USA, 2013. 724 pp. ISBN: 9781-4377-2264-2.

28. Hipp JA, Brunski JB, Cochran GV: Method of histological preparation of bone sections containing titanium implants. Stain technology. 1987; 62: 247-52.

29. Davies OG, Cooper PR, Shelton RM, Smith AJ, Scheven BA: A comparison of the in vitro mineralisation and dentinogenic potential of mesenchymal stem cells derived from adipose tissue, bone marrow and dental pulp. J Bone Miner Metab. 2015; 33:371-82.

30. Misawa MYO, Huynh-Ba G, Villar GM, Villar CC: Efficacy of stem cells on the healing of peri-implant defects: systematic review of preclinical studies. Clin Exp Dent Res. 2016 Feb 4; 2:18-34.

31. Egusa H, Sonoyama W, Nishimura M, Atsuta I, Akiyama K: Stem cells in dentistry - Part II: Clinical applications. J Prosthodont Res. 2012; 56:229-48.

32. Gustavo C Belmonte, Leandro A Holgado, Roger William de Labio, Patrícia Sammarco Rosa, Rosimeire Segato, Josianne T Fukasawa, Bruno Solano de Freitas Souza, Ricardo Ribeiro dos Santos, Oswaldo Baffa, Spencer L M Payão, Angela Kinoshita:The Potential of Human Dental Pulp Stem Cell from Deciduous Teeth in Bone Regeneration: An Experimental Study in Rabbits. International Journal of Oral and Dental Health. 2016; 2. ISSN: 2469-5734
33. Ito K, Yamada Y, Naiki T, Ueda M: Simultaneous implant placement and bone regeneration around dental implants using tissue-engineered bone with fibrin glue, mesenchymal stem cells and platelet-rich plasma. Clin Oral Implants Res. 2006; 17:579-86

34. Mark Saltzman W, Baldwin SP.: Materials for protein delivery in tissue engineering. Adv Drug Deliv Rev 1998; 33: 71- 86.

35. Luginbuehl V, Meinel L, Merkle HP, Gander B. Localized delivery of growth factors for bone repair. European Journal of Pharmaceutics and Biopharmaceutics. 2004; 58:197-208.

36. Wildemann B, Burkhardt N, Luebberstedt M, Vordemvenne T, Schmidmaier G.: Proliferating and differentiating effects of three different growth factors on pluripotent mesenchymal cells and osteoblast like cells. J Orthop Surg Res. 2007 Dec 20; 2:27.

37. Jung UW, Song KY, Kim CS, Lee YK, Cho KS, Kim CK, Choi SH.: Effects of a chitosan membrane coated with polylactic and polyglycolic acid on bone regeneration in a rat calvarial defect. Biomed Mater 2007; 3: 101-105.

38. R. Tanikonda, R.K. Ravi, Kantheti Sirisha, S. Divella: Chitosan: Applications in dentistry. Trends in Biomaterials and Artificial Organs. 2014; 28:74-78

39. d'Aquino R, De Rosa A, Lanza V, Tirino V, Laino L, Graziano A, Desiderio V, Laino G, Papaccio G.: Human mandible bone defect repair by the grafting of dental pulp stem/progenitor cellsand collagen sponge biocomplexes. Eur Cell Mater. 2009; 18:75-83

40. d'Aquino R, Graziano A, Sampaolesi M, Laino G Pirozzi G, De Rosa A, Papaccio G: Human postnatal dental pulp cells co-differentiate into osteoblasts and endotheliocytes: a pivotal synergy leading to adult bone tissue formation. Cell Cell Death Differ. 2007; 14:1162-71. Epub 2007 Mar 9.

41. Graziano A, d'Aquino R, Laino G, Proto A, Giuliano MT, Pirozzi G, De Rosa A, Di Napoli D, Papaccio G.: Human CD34+ stem cells produce bone nodules in vivo. Cell Prolif. 2008; 41:1-11. doi: 10.1111/j.1365-2184.2007.00497.

42. Baofeng L, Zhi Y, Bei C, Guolin M, Qingshui Y, Jian L.: Characterization of a rabbit osteoporosis model induced by ovariectomy and glucocorticoid Acta Orthop. 2010; 81: 396-401

43. Wancket LM: Animal Models for Evaluation of Bone Implants and Devices: Comparative Bone Structure and Common Model Uses. Vet Pathol. 2015, 52: 842-850 
44. Himanshu Arora, Anil Nafria, Anup Kanase: Rabbits as Animal Models in Contemporary Implant Biomaterial Research. World Journal of Dentistry, 2011; 2:129-134

45. Bressan E, Carraro A, Ferroni L, Gardin C, Sbricoli L, Guazzo R, Stellini E, Roman M, Pinton P, Sivolella S, Zavan B.: Nanotechnology to drive stem cell commitment. Nanomedicine (Lond) 2013; 8: 469-86.

46. Bressan E, Botticelli D, Sivolella S, Bengazi F, Guazzo R, Sbricoli L, Ricci S, Ferroni L, Gardin C, Velez JU, Zavan B.: Adipose-Derived Stem Cells as a Tool for Dental Implant Osseointegration: an Experimental Study in the Dog. Int J Mol Cell Med. 2015; 4:197-208.
47. Suh JK, Matthew HW.: Application of chitosan based polysaccharide biomaterials in cartilage tissue engineering: a review. Biomaterials. 2000; 21:2589-98.

48. Kim KS, Lee JH, Ahn HH, Lee JY, Khang G, Lee B: The osteogenic differentiation of rat muscle-derived stem cells in vivo within in situ-forming chitosan scaffolds. Biomaterials. 2008; 29: 4420-4428

49. Maglione M, Spano S, Ruaro ME, Salvador E, Zanconati F, Tromba G, Turco G: In vivo evaluation of chitosan glycerol gel scaffolds seeded with stem cells for full thickness mandibular bone regeneration. J Oral Sci. 2017; 59: 225-232. 